\title{
Mycobacterium xenopi IS1395, a novel insertion sequence expanding the IS256 family
}

\author{
M. Picardeau, ${ }^{1}$ A. Varnerot, ${ }^{1}$ J. Rauzier, ${ }^{2}$ B. Gicquel ${ }^{2}$ and V. Vincent ${ }^{1}$ \\ Author for correspondence: V. Vincent. Tel: +33145688360 . Fax: + 33140613118. \\ c-mail : vvincent@pastcur.fr
}

Laboratoire de Référence des Mycobactéries ${ }^{1}$ and Unité de Génétique Mycobactérienne ${ }^{2}$,

Institut Pasteur, 75724

Paris cedex 15 , France

\begin{abstract}
An insertion sequence (IS) of Mycobacterium xenopi has been isolated and sequenced. This 1323 bp element, designated IS1395, is present in up to 18 copies in the $M$. xenopi genome and may be harboured in an $M$. xenopi extrachromosomal element. It encodes a putative transposase of $\mathbf{4 1 5}$ amino acids which displays sequence homology to the Staphylococcus aureus IS256 family. Members of this class of elements have been described in the genus Mycobacterium - for example IS1081 is present in the $M$. tuberculosis complex, IS1245-IS 1311 in $M$. avium, and IS6120 in M. smegmatis : these elements exhibit an $89 \%, 45 \%$ and $16 \%$ amino acid identity with IS 1395, respectively. Investigation of the host range of IS 1395 by Southern blot analysis revealed additional IS1395-related repeated sequences in $\boldsymbol{M}$. gordonae and $\boldsymbol{M}$. celatum. Moreover, IS 1395 represents a useful epidemiological tool for $M$. xenopi strain typing as it provides a diversity of restriction fragment length polymorphism patterns.
\end{abstract}

Keywords: M. xenopi, IS1395, IS256 family, RFLP typing

\section{INTRODUCTION}

Mycobacterium xenopi was first isolated from a toad (Schwabacher, 1959), but was not recognized as a human pathogen until 1965 (Marks \& Schwabacher, 1965). Along with $M$. avium and $M$. kansasii, $M$. xenopi represents one of the commonest agents of mycobacterial pulmonary infections other than tuberculosis (Wolinsky, 1992). All of these organisms may colonize individuals without causing any damage; disease is usually encountered in patients presenting pre-existing lung disorders. Clinical, radiological and histopathological presentation is similar to that of tuberculosis and bacteriological findings are the only way of determining the causal agent. Unlike tuberculosis, notification of cases due to these potentially pathogenic mycobacteria is not mandatory and the actual incidence of related diseases is difficult to estimate. Moreover, the relative incidence of infections involving mycobacterial species varies significantly according to geographical area. The highest percentage of pulmonary infections due to $M$. xenopi is encountered in Western

The GenBank accession number for the 151395 sequence reported in this paper is U35051.

Abbreviations: IS, insertion sequence; $I R$, inverted repeat; $D R$, direct repeat.
Europe and the lowest in Japan and the USA. Rare extrapulmonary cases have been described in nonimmunocompromised patients, whereas disseminated infections have been diagnosed in patients eithet transiently or chronically immunocompromised (Wayne \& Sramek, 1992). Like other potentially pathogenic mycobacteria, $M$. xenopi is widely present in the environment, especially in tap water. Whereas clusters of cases tend to occut, human-to-human transmission has never been demonstrated and environmental sources of infection are likely. However, detailed investigation of animal and envitonmental reservoirs, as well as the determination of transmission routes and infection modes, requires precise strain-typing techniques.

There are two widely used molecular epidemiological methods for characterization of strains by genomic fingerprinting: pulsed-field gel electrophoresis (PFGE), and restriction fragment length polymorphism (RFLP) upon hybridization to specific probes. Ribotyping, a method of general use for bacteria, cannot be used in mycobacteria as they contain only one or two genes encoding rRNA (Bercovier et al., 1985). The insertion sequence (IS) IS6110, specific for tubercle bacilli, has been demonstrated to be a valuable epidemiological tool to establish strain relatedness relying on RFLP patterns (van Embden et al., 1992). Several other repeated DNA sequences have been described in mycobacteria, some 
providing genetic markers for species identification or strain differentiation (MacAdam et al., 1994; Poulet \& Cole, 1995; van Soolingen et al., 1993). Moreover, analysis of IS structures may allow determination of evolutionary relationships between species and contribute to phylogenetic and taxonomic studies.

IS1081, isolated from M. bovis, is present in five to seven copies in strains of the $M$. tuberculosis complex and revealed very few RFLPs (van Soolingen $e t$ al., 1992, 1993; Collins \& Stephens, 1991 ; Collins et al., 1993). An investigation of its host range showed cross-hybridization between $M$. bovis IS1081 and an unidentified repeated element in M. xenopi (Collins et al., 1993; Collins, 1994).

In the present study, we screened a partial $M$. xenopi genomic library with an IS1081 probe. A clone was selected from which a new IS was isolated, designated IS 1395, the molecular properties of which are presented here. Furthermore, the usefulness of this repetitive element for molecular strain typing within the species $M$. xenopi was analysed.

\section{METHODS}

Mycobacterial isolates. $M$. xenopi strains used in this study were isolated from clinical samples from different patients (Table 1).

Strains of eleven other mycobacterial species, $M$. avium, $M$. bovis, $M$. intracellulare, $M$. marinum, $M$. gordonae, $M$. smegmatis, $M$.

Table 1. $M$. xenopi strains used in the RFLP and PFGE studies

\begin{tabular}{|lrll|}
\hline Strain no. & Patient & \multicolumn{1}{c|}{ Source } & \multicolumn{1}{c|}{ Reference } \\
\hline 950291 & A & Bronchial wash & Our laboratory \\
950312 & B & Sputum & Our laboratory \\
950703 & C & Sputum & Our laboratory \\
950652 & D & Gastric aspirate & Our laboratory \\
950358 & E & Gastric aspirate & Our laboratory \\
950617 & F & Unknown & Our laboratory \\
950661 & G & Sputum & Our laboratory \\
950883 & H & Bronchial wash & Our laboratory \\
941206 & I & Sputum & M. Kubir* \\
950556 & J & Lymph node & Our laboratory \\
951123 & K & Bloodt & Our laboratory \\
951064 & L & Gastric aspirate & Our laboratory \\
930001 & M & Gastric aspirate & Our laboratory \\
950895 & N & Bronchial wash* & Our laboratory \\
950818 & O & Sputum & Our laboratory \\
941212 & P & Sputum & M. Kubin \\
941059 & Q & Sputum & Our laboratory \\
930826 & R & Vertebral bone & M. Duffaux-Fauville \\
930789 & S & Unknown & Our laboratory \\
\hline
\end{tabular}

* National Institute of Public Health, Prague, Czech Republic.

† Strain isolated from patient with AIDS.

$\ddagger$ Institut Pasteur du Brabant, Brussels, Belgium.
Table 2. Mycobacterium species used in this study

\begin{tabular}{|lcl|}
\hline Mycobacterium species & Strain no. & Source or reference \\
\hline M. xenopi & 930664 & Our laboratory \\
M. bovis & 14002 & CIP'T \\
M. smegmatis & 14133 & CIPT \\
M. gordonde & 14021 & CIPT \\
M. chelonae & 14042 & CIP'T \\
M. fortuitum & 14041 & CIPT \\
M. marinum & 14012 & CIPT \\
M. avium & 950495 & Our laboratory \\
M. intracellulare & 14031 & CIPT \\
M. kansasii & 14011 & CIPT \\
M. celatum & 931227 & W. R. Butler $\dagger$ \\
M. terrat & 14032 & CIPT \\
\hline
\end{tabular}

* CIPT: Collection Institut Pasteur Tuberculose, Institut Pasteur, Paris, France

† National Center for Infectious Diseases, Centers for Disease Control and Prevention, Atlanta, GA, USA.

terrae, $M$. celatum, $M$. chelonae, $M$. fortuitum and $M$. kansasii, were investigated to define the host range of IS1395 (Table 2).

Genomic DNA preparation for molecular cloning and RFLP. Mycobacterial strains were grown in $5 \mathrm{ml}$ Middlebrook $7 \mathrm{H} 9$ broth containing $1 \mathrm{mg} \mathrm{D}$-cycloserine $\mathrm{ml}^{-1}$ and incubated overnight at $37^{\circ} \mathrm{C}$. Cells were heated for $20 \mathrm{~min}$ at $80^{\circ} \mathrm{C}$, centrifuged, resuspended in $250 \mu$ of $25 \%(\mathrm{w} / \mathrm{v})$ sucrose, $50 \mathrm{mM}$ Tris/ $\mathrm{HCl} \mathrm{pH} 8 \cdot 0,50 \mathrm{mM}$ EDTA containing $500 \mu \mathrm{g}$ lysozyme $\mathrm{ml}^{-1}$ and incubated overnight. Then $250 \mu \mathrm{l}$ of a solution consisting of $100 \mathrm{mM}$ Tris/ $\mathrm{HCl}, 1 \%$ (w/v) SDS and $400 \mu \mathrm{g}$ proteinase $\mathrm{K} \mathrm{ml}^{-1}$ was added and the sample incubated for $4 \mathrm{~h}$ at $55^{\circ} \mathrm{C}$. DNA was extracted with phenol/chloroform, precipitated with ethanol and dissolved in TE $(10 \mathrm{mM}$ Tris/ $\mathrm{HCl}$, $\mathrm{pH} 8 \cdot 0,1 \mathrm{mM}$ EDTA).

Molecular cloning and library screening.'Three micrograms of M. xenopi DNA was digested with Bam $\mathrm{HI}$ and separated on a $0-8 \%(\mathrm{w} / \mathrm{v})$ agarose gel. Restriction fragments of approximately 1-4 kbp were recovered from the agarose gel by electroelution into sterile water using a dialysis membrane. DNA was purified by phenol/chloroform extraction followed by ethanol precipitation and ligated into the BamHI site of the plasmid pBluescript II $\mathrm{KS}^{+j-}$ (Stratagene).

Ligation mixtures were transformed into Escherichia coli DH5 $\alpha$ by electroporation (Gene Pulser unit; Bio-Rad). Recombinant colonies were selected on Luria-Bertani solid medium $(10 \mathrm{~g}$ Bacto-tryptone $\mathrm{l}^{-1}, 5 \mathrm{~g}$ yeast extract $\mathrm{l}^{-1}, 10 \mathrm{~g} \mathrm{NaCl} \mathrm{l}^{-1}, \mathrm{pH} 7 \cdot 5$, supplemented with $100 \mu \mathrm{g}$ ampicillin $\mathrm{ml}^{-1}$ ) and then transferred onto a nylon filter ( $\mathrm{N}^{+}$Hybond; Amersham) by standard techniques (Sambrook et al., 1989).

IS 1081 probe was prepared from a $M$. bovis strain as described by Collins et al. (1993), labelled with $\left[\alpha^{-32} \mathrm{P}\right] \mathrm{dCTP}$ by using the Megaprime DNA-labelling kit (Amersham), and hybridized to the filters overnight at $65^{\circ} \mathrm{C}$ in Rapid hybridization buffer (Amersham) followed by stringent washes at $65^{\circ} \mathrm{C}$ : twice for 10 min each in $2 \times \mathrm{SSC}(1 \times \mathrm{SSC}$ is $0.15 \mathrm{M}$ sodium chloride plus $0.015 \mathrm{M}$ sodium citrate), $0.1 \%(\mathrm{w} / \mathrm{v})$ SDS; twice for $10 \mathrm{~min}$ each in $1 \times$ SSC, $0.1 \%(\mathrm{w} / \mathrm{v}) \mathrm{SDS}$ and once for $10 \mathrm{~min}$ in $0.1 \times$ $\mathrm{SSC}, 0 \cdot 1 \%(\mathrm{w} / \mathrm{v}) \mathrm{SDS}$. 


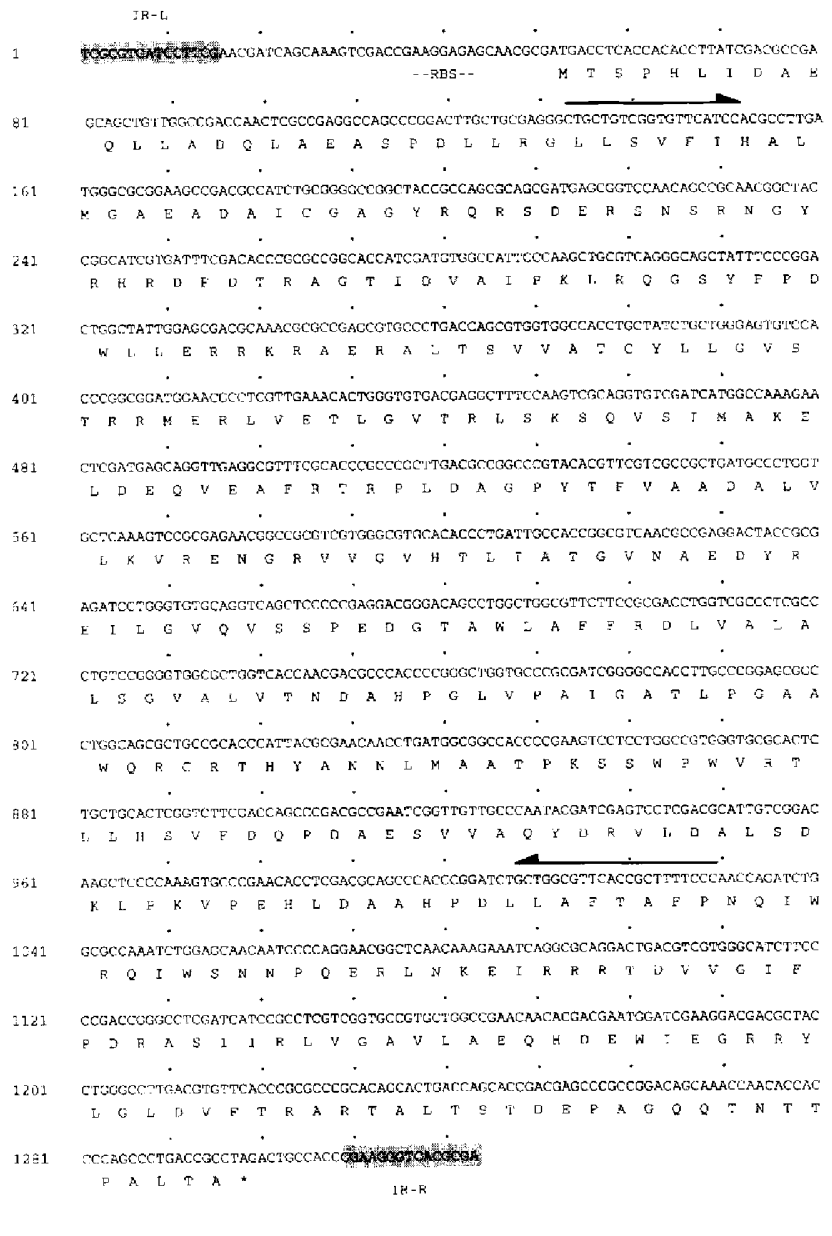

Fig. 1. Nucleotide and amino acid sequences of $M$. xenopi IS1395. Imperfect inverted repeats, designated IR-R and IR-L, are shaded. The targets of the primers XNA and XNB used for IS1395 probe preparation are indicated by arrows above the sequence. The deduced amino acid sequence is shown below the DNA sequence, the asterisk indicates the putative transposase termination codon and a potential ribosomebinding site (RBS) is identified.

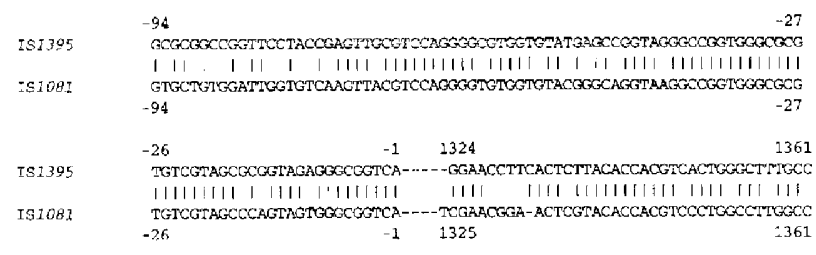

Fig. 2. Comparison of insertion sites of $M$. bovis 151081 and $M$. xenopi IS1395 in the recombinant plasmids pB5 (Collins \& Stephens, 1991) and pMP1 respectively (this study). The gaps correspond to the IS elements.

Plasmid pMP1 to be used for DNA sequence analysis was purified using Qiagen mini-columns (Qiagen 'Midi' Kit).

Sequencing and analysis. Sequences of double-stranded plasmid DNA were determined by the dideoxynucleotide chaintermination method (Sanger et al., 1977) using the Taq
DyeDeoxy Terminator Cycle sequencing kit (Applied Biosystems), on a GeneAmp PCR System 9600 (Perkin Elmer), and run on a DNA Analysis system model 373 stretch (Applied Biosystems). The sequencing was performed by using a DNA walking strategy along the $2 \mathrm{kbp}$ pMP1 insert.

Similarities with IS1395 were found in databases by using BLAST (Altschul et al., 1990) and FASTA (Pearson \& Lipman, 1988) algorithms. Deduced amino acid sequences from IS1395 and members of the 15256 family were aligned by using CLLSTAL $w$ software (Thompson et al., 1994). A distance matrix was produced by using pRoTDIST from PHYLIP 3.5 (J. Felsenstein, University of Washington), according to the method of Dayhoff, and a tree was constructed by the neighbour-joining method.

PCR. Sequence analysis of IS1395 allowed the selection of primers XNA (5' CTG CTG TCG GTG 'TC A'TC C 3') and XNB (5' GGG AAA AGC GGT GAA CGC CAG C $3^{\prime}$ ) at positions 133-151 and 1008-1029, respectively (Fig. 1). The two primers XNA and XNB were used to generate a 897 bp probe for RFLP analysis and to define the host range of IS1395 in PCR tests performed with target DNAs from different mycobacterial species (Table 2). DNA sources consisted of crude lysates obtained by heating cell suspensions at $100^{\circ} \mathrm{C}$ for $30 \mathrm{~min}$. For this purpose, a loopful of mycobacteria was suspended in $100 \mu \mathrm{I}$ TE containing $1 \%(\mathrm{v} / \mathrm{v})$ Triton $\mathrm{X}-100$.

Amplification reactions were performed with $50 \mu \mathrm{l}$ volumes containing $1 \times$ Taq polymerase buffer $(50 \mathrm{mM}$ Tris $/ \mathrm{HCl}$ pH 8.3, $50 \mathrm{mM} \mathrm{KCl}, 0.01 \%$, w $/ v$, gelatin) $1.5 \mathrm{mM} \mathrm{MgCl}_{2}, 200 \mu \mathrm{M}$ each deoxynucleoside triphosphate, $1 \mu \mathrm{mol}$ primers $\mathrm{XNA}$ and $\mathrm{XNB}$, and $2 \mathrm{U}$ Taq polymerase (Perkin Elmer) covered with mineral oil. Two microlitres of template DNA prepared as indicated above was added to the mix. The 35 amplification cycles ( $1 \mathrm{~min}$ at $95^{\circ} \mathrm{C} ; 1 \mathrm{~min}$ at $65^{\circ} \mathrm{C} ; 1 \mathrm{~min}$ at $72^{\circ} \mathrm{C}$ ) were followed by a 10 min extension at $72^{\circ} \mathrm{C}$ in a Perkin Elmer thermocycler. Amplification products were analysed by electrophoresis on a $1.2 \%(\mathrm{w} / \mathrm{v})$ agarose gel and detected by ethidium bromide staining.

RFLP. The 897 bp probe within 151395 was prepared as described above, purified from agarose gel according to the GeneClean procedure (Bio101) and labelled with horseradish peroxidase using the ECL system (Amersham).

Two micrograms of mycobacterial DNA was digested with $10 \mathrm{U} P u n l$ in a $30 \mu \mathrm{l}$ reaction mixture. DNA fragments were resolved by overnight electrophoresis on a $1 \%(\mathrm{w} / \mathrm{v})$ agarose gel at $1.5 \mathrm{~V} \mathrm{~cm}$ and transferred to a nylon membrane $\left(\mathrm{N}^{+}\right.$ Hybond; Amersham) (Sambrook et al., 1989). The membrane was hybridized overnight at $42^{\circ} \mathrm{C}$ with the probe, then washed twice for $10 \mathrm{~min}$ at $55^{\circ} \mathrm{C}$ with $0.5 \times \mathrm{SSC}$ containing $0.4 \%$ $(w / v)$ SDS, and finally washed twice for $5 \mathrm{~min}$ at room temperature with $2 \times$ SSC. The peroxidase-labelled probe was detected with the ECL detection system (Amersham).

Host range investigation. Mycobacterial DNAs from different species (Table 2) were digested with PvuII, transferted to a nylon membrane and probed with the $897 \mathrm{bp}$ fragment within IS1395 labelled with ${ }^{32} \mathrm{P}$ as described above (Fig. 4).

PFGE. $M$. xenopi isolates were cultivated in $5 \mathrm{ml}$ Middlebrook $7 \mathrm{H} 9$ broth. Cultures were inoculated into $40 \mathrm{ml}$ fresh medium at an $\mathrm{OD}_{650}$ of $0 \cdot 08$, and incubated at $42^{\circ} \mathrm{C}$ till an $\mathrm{OD}_{650}$ of $0 \cdot 2$ was obtained. Cells were centrifuged, resuspended in $1 \%(\mathrm{v} / \mathrm{v})$ Triton $\mathrm{X}-100$ and incubated for $2 \mathrm{~h}$ at $37^{\circ} \mathrm{C}$. They were then centrifuged again, washed in $0.05 \mathrm{M}$ EDTA and resuspended in $10 \mathrm{mM}$ Tris $/ \mathrm{HCl} \mathrm{pH} 8.0$, containing $100 \mathrm{mM}$ EDTA and $1 \mathrm{mg}$ lysozyme $\mathrm{ml}^{-1}$. The suspension was then mixed with an equal 


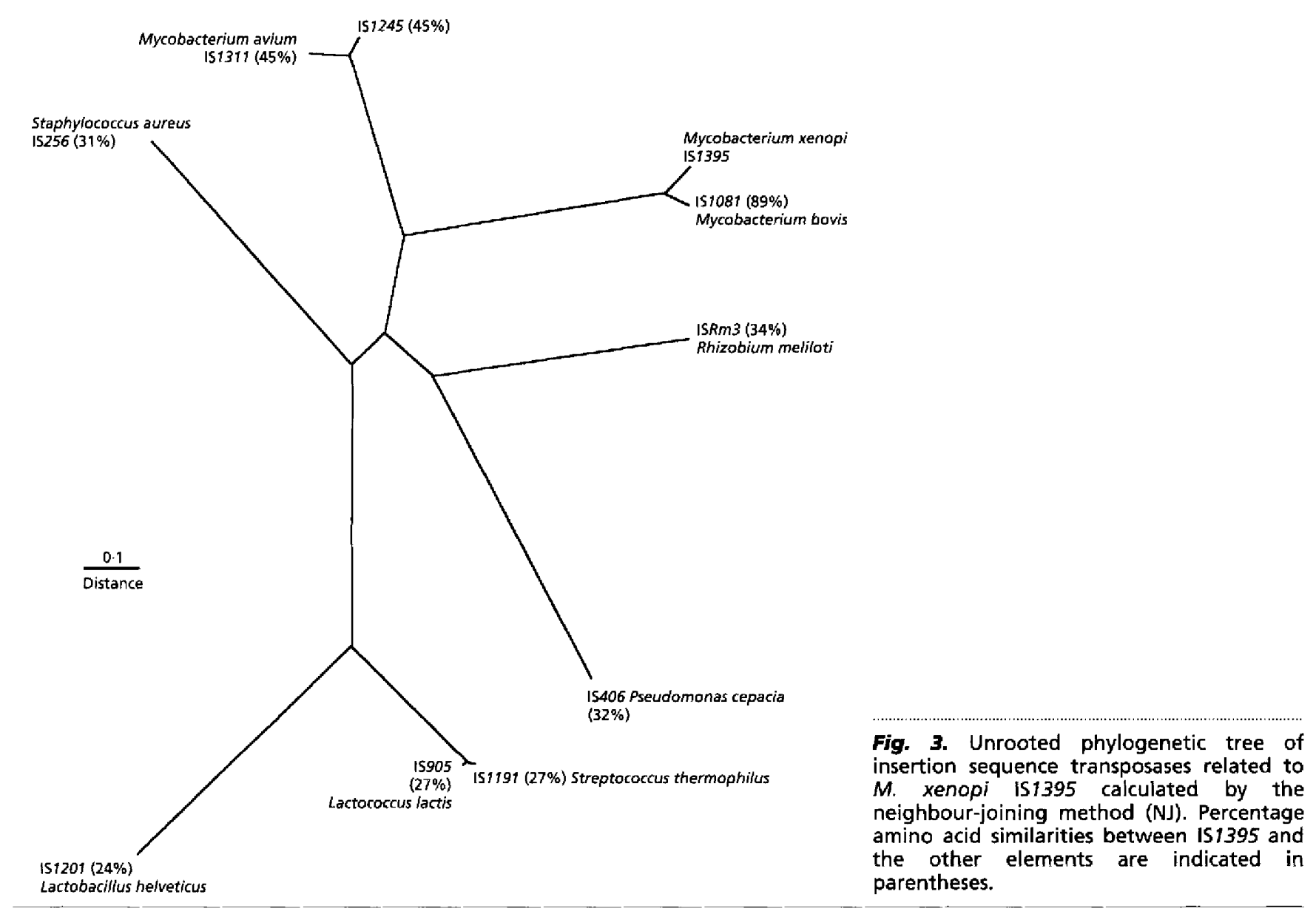

volume of $1 \%(\mathrm{w} / \mathrm{v})$ low-melting-point agatose and dispensed in a slot former of $60 \mu$. Plugs were incubated in $0.5 \mathrm{M}$ EDTA for $24 \mathrm{~h}$ at $37^{\circ} \mathrm{C}$, then washed in TE and incubated in $1 \%(\mathrm{w} / \mathrm{v})$ sodium $N$-lautoylsarcosinate (Sigma) and $2 \mathrm{mg}$ proteinase $\mathrm{K}$ $\mathrm{mi}^{-1}$ for an extra night at $55^{\circ} \mathrm{C}$. Plugs were washed in TE and incubated in TE containing $4 \mu \mathrm{g} \mathrm{PMSF} \mathrm{m}{ }^{-1}$ (Sigma) for $1 \mathrm{~h}$ at $55^{\circ} \mathrm{C}$ to inactivate proteinase $\mathrm{K}$. Finally, plugs were extensively washed in TE and digested with $30 \mathrm{U}$ DraI. After digestion, plugs were loaded onto a $0.8 \%(\mathrm{w} / \mathrm{v})$ agarose gel. Large restriction fragments were separated by zero-integrated-field electrophoresis (ZIFE) with the AutoBase system (Q-Life Systems) for $65 \mathrm{~h}$ at room temperature with the $8-200 \mathrm{~kb}$ ROM card.

\section{RESULTS}

\section{Description of IS1395}

In this study, we produced an $M$. xenopi partial library of BamHI-digested genomic DNA and screened it using an IS1081 probe prepared from $M$. bovis as described by Collins et al. (1993). One recombinant clone gave a strong hybridization signal suggesting the presence of the IS1081-like element. Further analysis of this clone revealed that it contained a plasmid, named pMP1, harbouring a DNA insert of approximately $2 \mathrm{kbp}$.

DNA sequencing of the pMP1 insert revealed the characteristic features of an IS. This element, designated IS1395, is 1323 bp long and contains at its extremities $15 \mathrm{bp}$ inverted repeats (IR) with one mismatch (Fig. 1). The base composition is typical of mycobacteria, with a $65.2 \mathrm{~mol} \% \mathrm{G}+\mathrm{C}$ content. Analysis of the sequence showed the presence of a large ORF which could encode a protein of 415 amino acids with ATG as a putative start codon at position 52 and preceded by a potential ribosome-binding site at the expected position (Fig. 1). The transposases of the other IS256 mycobacterial elements (described below) have the same start codon.

The GenBank database was screened to identify elements related to IS1395. The nucleotide sequence showed $86 \%$ homology to $M$. bovis IS1081, and less significant homologies to $M$. avium IS1311/IS1245 and Pseudomonas cepacia IS406. Moreover, comparison of the IS1395 to the $M$. bovis/M. bovis BCG IS1081 flanking regions revealed $86 \%$ identity in a 39 bp overlap with the 'right arm' and $79 \%$ identity in a 91 bp overlap with the 'left arm' (Fig. 2). These flanking regions did not present peculiar base composition or direct repeats (DR).

When protein databases were screened for elements homologous to the putative protein encoded by the large ORF, significant homologies were found with putative transposases belonging to the Stapbylococcus aureur IS256 


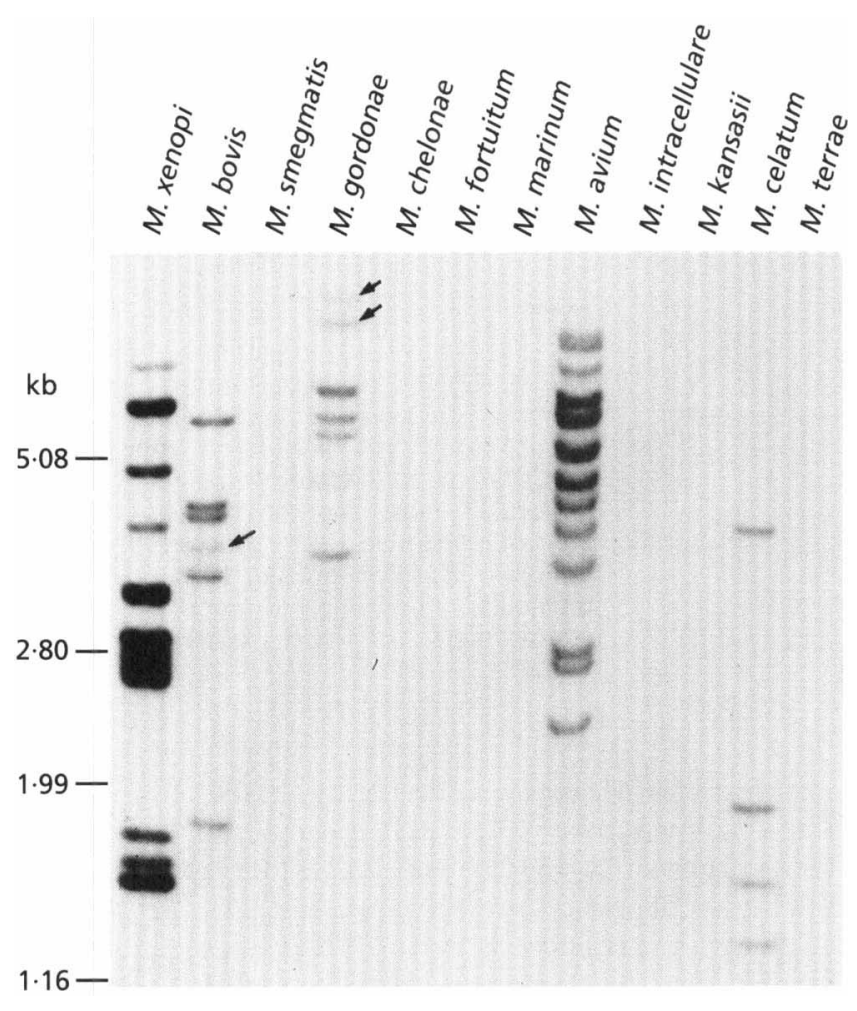

Fig. 4. Southern blot analysis of Pvull-digested DNAs of mycobacterial species probed with I\$1395. The molecular mass marker is bacteriophage $\lambda$ DNA restricted by Pstl. The weak bands indicated by arrows are better visualized after a longer exposure.

family. Amino acid sequence comparisons revealed the highest scores for transposases from $M$. bovis IS1081, M. avium IS 1245 and IS1311, Rbizobium meliloti ISR 3 , $P$. cepacia IS406 and $S$. aureus IS256. A phylogenetic tree based on amino acid sequence similarities was constructed by the neighbour-joining method (Fig. 3).

\section{IS1395 host range}

The occurrence of IS1395 among members of the genus Mycobacterium was investigated by hybridization of digested DNA from different mycobacterial species with IS1395. Patterns consisting of several bands were displayed by DNA from $M$. bovis, $M$. gordonae, $M$. avium and $M$. celatum whereas no hybridization was detected for DNA from the other species examined (Fig. 4). Identical patterns were obtained for $M$. bovis and $M$. avium when using IS 1081 and IS1245/IS1311 as respective probes, confirming that hybridization occurred with these IS1395related elements. Moreover PCR tests performed with primers XNA and XNB allowed for the amplification of the expected $897 \mathrm{bp}$ fragment within IS1395 in DNA templates from $M$. xenopi only and did not yield any amplified products with DNA templates from the other mycobacterial species listed in Table 2 (data not shown).

\section{Distribution of IS1395 within $M$. xenopi strains}

PFGE of $M$. xenopi non-digested genomic DN $A$ revealed an extra-chromosomal element in all strains (Fig. 5a). Using different electrophoresis conditions with changes in pulse duration, the mobility of the extra-chromosomal DNA was consistent with a linear fragment with a molecular mass in the region of $150 \mathrm{kbp}$. PFGE was performed in the presence or the absence of the intercalating agent ethidium bromide in order to distinguish between linear and supercoiled circular DNA (data not shown). The estimated size of the extra-chromosomal element was unaffected by the presence of ethidium bromide. These findings were consistent with linearity of the element (Ferdows et al., 1996). To our knowledge, this is the first linear extra-chromosomal element ever described in mycobacteria.

Following PFGE, DNA was blotted and probed with IS1395. Hybridizing bands were visualized on the chromosomes of all the strains. An additional signal was observed on the extra-chromosomal element in one instance as shown in Fig. 5, lane 8. Because of PFGE conditions adapted to the resolution of large DNA fragments, the molecular mass of the extra-chromosomal element harbouring the IS could not be differentiated from that of the extra-chromosomal element devoid of IS1395.

To study the RFLP of the repetitive element among $M$. xenopi strains, primers XNA and XNB were designed to produce an IS 1395 internal probe. PvuII was used for genome digestion as IS1395 did not contain a corresponding restriction site.

Analysis of the Southern blot of PvuII-digested DNAs of 19 non-related strains, i.e. clinical strains from different patients (Table 1), showed that IS1395 was present in multiple copies in the $M$. xenopi genome and generated strain-specific patterns. The copy number varied from 3 to 18 (median 14) (Fig. 6). Nevertheless, the DNA fingerprints observed were not highly polymorphic: the RFLP patterns displayed several bands in common. In the region of $2.5 \mathrm{kbp}, 15$ out of the 19 studied strains showed either five or two bands (Fig. 6a). Stability of the RFLP patterns was demonstrated by typing $M$. xenopi strains recovered from hospital tap water from July 1993 through June 1995. The 23 month interval did not lead to profile changes (data not shown). Therefore, despite its potential ability to transpose, IS 1395 is stable enough to be considered as an epidemiological marker useful for strain typing.

RFLP and PFGE analysis were conducted on the same strains to compare the epidemiological value of these techniques (lig. 6). The PFGE patterns consisted of about 25 large restriction fragments and, like RFLP profiles, presented bands shared by all strains. In our hands, the $200-300 \mathrm{kbp}$ range gave the best resolution and corresponded to the most polymorphic region. The two techniques afforded similar discrimination between strains. However RFLP could provide a better differentiation as observed in lanes $G$ and $H$ : the PFGE profiles 


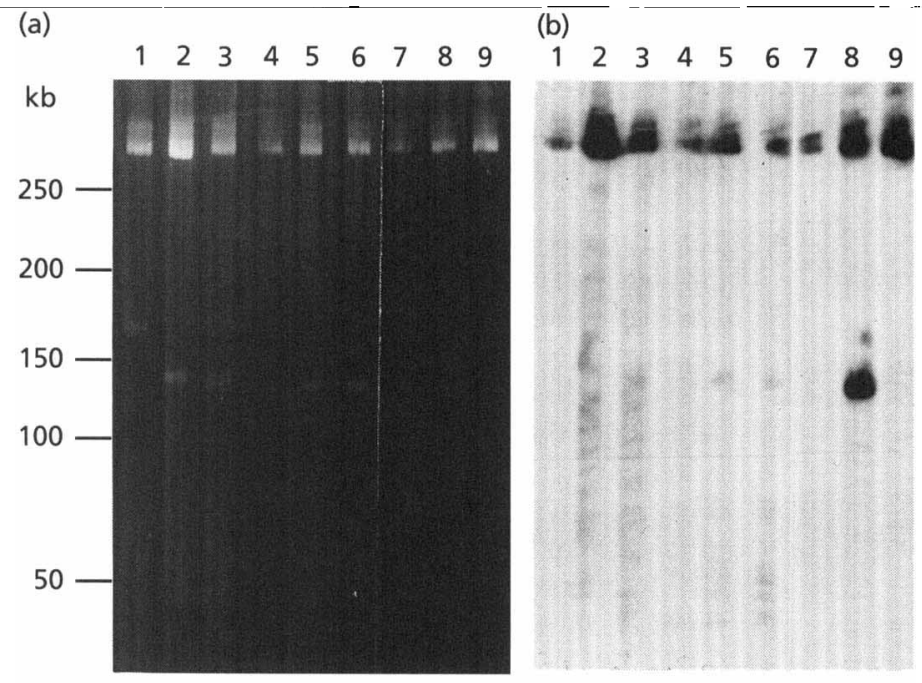

\begin{abstract}
Fig. 5. (a) PFGE separation of undigested genome of $M$. xenopi strains. Lanes 1 to 9 correspond to strains isolated from patients I, M, O, F, D, K, E, Q and N, respectively. The molecular mass marker consists of DNA concatemers of the bacteriophage $\lambda$ genome. (b) PFGE probed with IS1395. The molecular mass marker consists of DNA concatemers of the bacteriophage $\lambda$ genome.
\end{abstract}

were identical whereas the RFLP patterns differed by three bands.

\section{DISCUSSION}

Previous studies showed that $M$. xenopi contained an element related to IS 1081 , one of the repetitive DNA sequences specific for the tubercle bacilli (Collins et al., 1993; Collins, 1994). In the present study, IS1081 was used as a probe for screening an $M$. xenopi partial genomic library. This attempt led to the isolation of a new repetitive element, designated IS1395, which occurs in all $M$. xenopi strains tested. The entire 1323 bp nucleotide sequence was determined and revealed imperfect 15 bp terminal IR. A large ORF, which encodes a putative transposase of 415 amino acids, covers most of IS1395. The putative protein sequences of the different IS256 family members showed that mycobacterial elements belong to the two IS256 subclasses: one subclass comprises IS1081, specific for tubercle bacilli (van Soolingen et al., 1992), IS1245 and IS1311, specific for M. avium (Guerrero et al, 1995; Roiz et al., 1995) and IS1395, whereas IS6120 (from $M$. smegmatis) belongs to the other IS256 subclass, characterized by a large ORF preceded by a smaller one (Guilhot et al., 1992).

The IS1395 and IS 1081 left and right flanking sequences displayed a high percentage of identity over 130 nucleotides (Fig. 2), whereas homology no other sequence in the databases could be detected. A recent study showed that IS1081 cloned from $M$. bovis BCG exhibited the same flanking sequence as that of IS 1081 previously isolated from a $M$. bovis strain (Collins \& Stephens, 1991). Moreover, the sequence of the $5^{\prime}$ end of an IS1395 copy harboured by a Pst I restriction fragment showed an identical flanking sequence (data not shown). These results indicate that IS1081 and IS1395 ate inserted at specific identical positions on the chromosome, accounting for the limited polymorphism generated by IS1081 in tubercle bacilli. However, although RFLP shows that most $M$. xenopi strains have several IS1395 copies in the same chromosomal loci, IS1395 provides useful poly- morphism for $M$. xenopi strain typing, based on variations of both copy number and distribution within the genome. This suggests that IS1081 has a lower degree of mobility or a higher degree of insertion specificity than IS1395. An alternative explanation is that $M$. bovis as a species is less variable than $M$. xenopi, and that the factors responsible for the greater homogeneity of $M$. bovis also result in less polymorphism of the IS. This latter explanation is also supported by the lack of polymorphism found in $M$. bovis when considering IS 6110 RFLP patterns (van Soolingen et al., 1992).

Whereas transposition events usually generate duplication of a few nucleotides of the target site (Galas \& Chandler, 1989), no DR could be detected in the IS 1081 or IS1395 flanking sequences.

The high percentage homology between the IS1395 from $M$. xenopi and IS1081 from M. bovis may indicate that the element existed before the divergence of the organisms or that a horizontal transfer occurred later after the divergence. Since the species which host IS256-related clements are taxonomically remote, a hotizontal gene tratisfer may be hypothesized. It has been demonstrated in different Gram-positive species that IS256 and related ISs can coexist in multiple copies in a cell on both plasmids and chromosome (Wheatford \& Laberge, 1991; Hesselbarth et al., 1995). In the present study, we characterized a large extra-chromosomal element in $M$. xenopi which, in one strain out of the nine tested, harboured IS 1395 , thus providing a plausible mechanism for IS transfer. In $M$. avium, plasmids of various moleculat mass have been found (Meissner \& Falkinham, 1986), but comparative analyses of IS distributions and plasmid profiles are lacking.

IS 1395 -related elements were detected in $M$. gordonae and $M$. celatum, a recently described opportunistic agent (Butler et al., 1993; Tortoli et al., 1995). The characterization of these related IS256 elements present in the two species will provide valuable information on the genetic relatedness and evolution of these mycobacteria. On the basis of $16 \mathrm{~S} \mathrm{rRNA}$ homology and phenotypic 
(a)
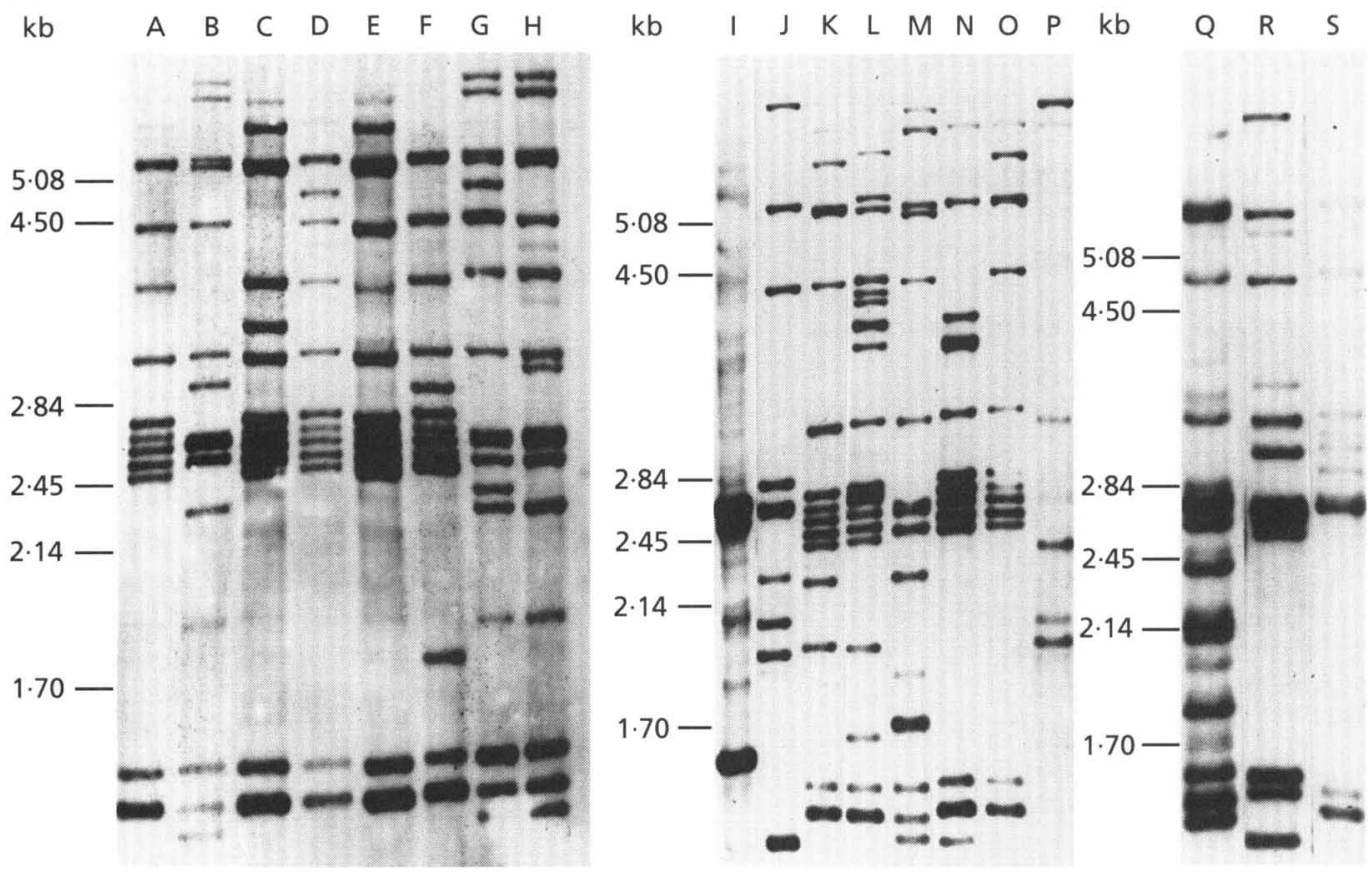

(b)
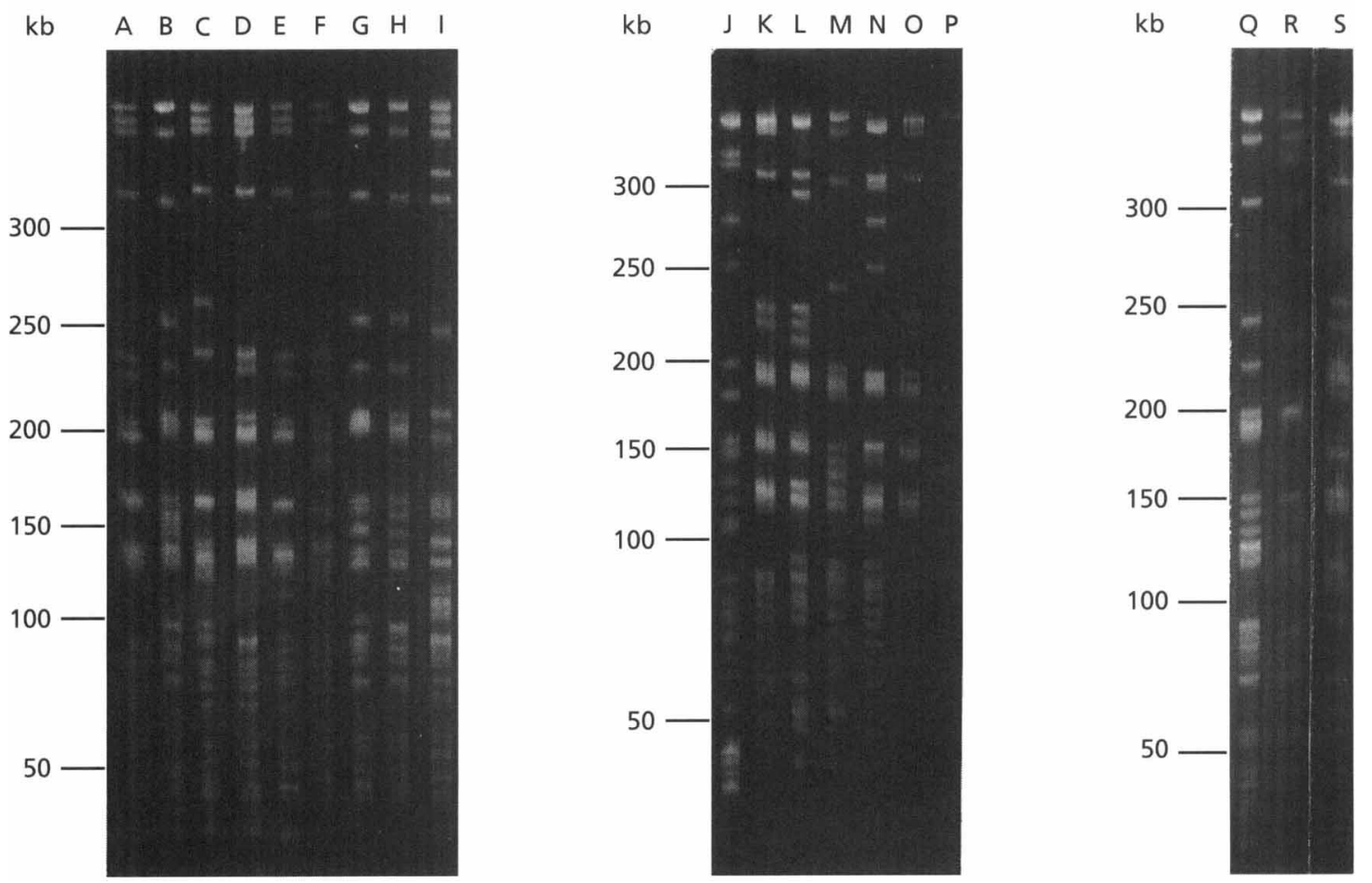

Fig. 6. (a) RFLP patterns of $M$. xenopi DNAs probed with IS1395. The molecular mass marker is bacteriophage $\lambda$ DNA restricted by Pstl. (b) PFGE patterns of $M$. xenopi DNA digested with Dral. The molecular mass marker consists of DNA concatemers of bacteriophage $\lambda$ genome. Lane designations correspond to the patient identifiers in Table 1.

biochemical tests, $M$. xenopi, $M$. avium and $M$. celatum are related species, whereas the $M$. tuberculosis complex or $M$. gordonae belong to distant taxonomic groups (Butler $t$ t al., 1993; Rogall et al., 1990). As indicated by Wayne et al.
(1996), in a semantide-based analysis of slowly growing mycobacteria, the attempt to base phylogenetic schemes on $16 \mathrm{~S}$ rRNA alone has not been confirmed, partly because the depth of branching in the tree somehow 
reflects the age of the branch. Very recently diverged species may not be distinguishable by $16 \mathrm{~S}$ rRNA sequencing (Fox et al., 1992). Trees constructed using other, independent semantides, e.g. DNA sequences of conserved genes (Kapur et al., 1995; Zolg \& PhilippiSchulz, 1994) or ISs, probably represent various molecular clocks. Analyses based on such diverse markers may contribute to shedding light on mycobacterial taxa not well resolved by $16 \mathrm{~S}+\mathrm{RNA}$ analysis and/or reveal some unexpected relatedness suggesting common ancestors for otherwise temote organisms.

As previously shown by Collins (1994), IS1081 may be used as an epidemiological marker to differentiate $M$. $x$ xenopi strains. Our study confirms these results, and RFLP patterns were found to be identical using IS1081 or IS1395 as probes (data not shown). RFLP analysis allowed to separate $M$. xenopi strains into two major 'sub-groups' according to the presence of five or two bands in the $2.5 \mathrm{kbp}$ region. Strain differentiation was comparable by RFI.P and by PFGE. PFGE patterns within each RFLP 'sub-group' were more homogeneous than patterns from different 'sub-groups'. As RFIP upon hybridization with IS1395 and PFGE after Dral digestion are two independent techniques (IS1395 has no Dral restriction site), which rely on the polymorphism of distinct DNA sequences, similarities observed between profiles with both methods stress the high homogeneity of the $M$. xenopi genome. Some strains indistinguishable by PFGE displayed distinct RFLP patterns. However, the demonstration of better performance for RFLP has to be established on a larger set of $M$. xenopi strains.

In conclusion, DNA fingerprinting with the IS1395 probe represents a potentially useful tool for epidemiological studies. Further epidemiological studies to evaluate this repctitive element ate under way, especially to determine possible relationships between RFLP patterns and $M$. xenopi sources (clinical isolates, environment, animals etc.). Moreover, the characterization of the molecular properties of the IS1395-related elements in $M$. gordonae and $M$, celatum will contribute to a better knowledge of mycobacterial ISs, their mode of transposition and dissemination.

\section{ACKNOWLEDGEMENTS}

We acknowledge C. Dauga for support with the application of the PIYLIP software. This work is part of a doctoral thesis in Microbiology presented by M.P., the recipient of a fellowship from Agence Nationale de Recherches sur le SIDA.

\section{REFERENCES}

Altschul, S. F., Gish, W., Miller, W., Myers, E. W. \& Lipman, D. J. (1990). Basic local alignment scarch tool. J Mol Biol 215, 403-410.

Bercovier, H., Kafri, O. \& Sela, S. (1985). Mycobacteria possess a surprisingly small number of ribosomal RNA genes in relation to the size of their genome. Biacbem Biophys Res Commun 136, $1136-1141$.

Butler, W. R., O'Connor, S. P., Yakrus, M. A., Smithwick, R. W.r Plikaytis, B. B., Moss, C. W., Floyd, M. M., Woodley, C. D., Kilburn, J. O., Vadney, F. S. \& Gross, W. M. (1993). Myrobacterium celatum sp. nov. Int J Syst Bacteriol 43, 539-548.
Collins, D. M. (1994). DNA fingcrptinting of Mycobaterium xenopi strains. I.ett Appl Microbiol 18, 234-235.

Colfins, D. M. \& Stephens, D. M. (1991). Identification of an insertion sequence, IS1081, in Mycobacterium bovis. FEMS Microbiol Lall 83, 11-16.

Collins, D. M., Erasmuson, S. K., Stephens, D. M., Yates, G. F. \& De Lisle, G. W. (1993). DNA fingerprinting of Mycobacterium bovis strains by restriction fragment analysis and hybridization with insertion elements IS 1081 and IS6110. J Clin Microbiol 31, 1143 1147.

van Embden, J. D. A., Cave, M. D., Crawford, J. T., Dale, J. W., Eisenach, K. D., Gicquel, B., Hermans, P. W. M., Martin, C., MacAdam, R., Shinnick, T. M. \& Small, P. M. (1992). Strain identification of Mycobacteritm twberculosis by DNA fingerprinting: recommendations for a standardized methodology. I Clin Microbiol 31, 406-409.

Ferdows, M. S., Serwer, P., Griess, G. A., Norris, S. J. \& Barbour, A. G. (1996). Conversion of a linear to a circular plasmid in the relapsing fever agent Borrelia bermsii. J Bacteriol 178, 793-800.

Fox, G. E., Wisotzkey, J. D. \& Jurtshuk, P., Jr (1992). How close is close: $16 \mathrm{~S}$ rRNA sequence identity may not be sufficient to guarantee species identity. Int J Syst Bacteriol 42, 166-170.

Galas, D. J. \& Chandler, M. (1989). Bacterial insertion elements. In Mobile DNA, pp. 109-162. Edited by D. E. Berg \& M. M. Howe. Washington, DC: American Society for Microbiology.

Guerrero, C., Bernasconi, C., Burki, D., Bodmer, T. \& Telenti, A. (1995). A novel insertion element from Mycobacterium avium, IS 1245, is a specific target for analysis of strain relatedness. I Clin Microbiol 33, $304-307$.

Guilhot, C., Gicquel, B., Davies, J. \& Martin, C. (1992). Isolation and analysis of IS6120, a new inscrtion sequence from Mycobacterium imegmatis. Mol Microbiol 6, 107-113.

Hesselbarth، J., Werckenthin, C., Liebisch, B. \& Schwarz, S. (1995). Insertion elements in Staplylococous intermedius. Lett Appl Microbiol 20, 180-183.

Kapur, V., Ling, L. L., Hamrick, M. R., Plikaytis, B. B., Shinnick, T. M., Telenti, A., Jacobs, W. R., Jr, Banerjee, A., Cole, S., Yuen, K. Y., Clarridge, J. E., Kreiswirth, B. N. \& Musser, J. M. (1995). Rapid Mycobacterium species assignment and unambiguous identification of mutations associated with antimicrobial resistance in $\mathrm{Myc}$ bacteriam thberulosis by automated DNA sequencing. Arib Pathol Lab Med 119, 131138.

MacAdam, R. A., Guilhot, C. \& Gicquel, B. (1994). Transposition in mycobacteria. In Tuberculosis: Pathogenesis, Protection, and Control, pp. 199-216. Edited by B. R. Bloom. Washington, DC: American Society for Microbiology.

Marks, J. \& Schwabacher, H. (1965). Infection due to Mycobacterinm xenopi. Br Med J 1, 32.

Meissner, P. M. \& Falkinham, J. O., III (1986). Plasmid DNA profiles as epidemiological markers for clinical and environmental isolates of Mycobacterium avium, Mycobacterium intracellulare and Mycobacterium scrofulaceum. I Infect Dis 153, 325-331.

Pearson, W. R. \& Lipman, D. J. (1988). Improved tools for biological sequence comparison. Proc Natl Acad Sci US A 85, 2444-2448.

Poulet, S. \& Cole, 5.T. (1995). Repeated DNA sequences in mycobacteria. Arcb Microbiol 163, 79-86.

Rogall, T., Wolters, J., Flohr, T. \& Böttger, E. C. (1990). Towards a phylogeny and definition of species at the molecular level within the genus Mycobacterium. Int J Syst Bacteriol 40, 323-330.

Roiz, M. P., Palenque, E., Guerrero, C. \& Garcia, M. J. (1995). Use of restriction fragment length polymorphism as a genetic marker 
for typing Mycobacterimm avium strains. J Clin Microbiol 33, 13891391 .

Sambrook, J., Fritsch, E. F. \& Maniatis, T. (1989). Molecular Cloning: a Laboratory Manual, 2nd edn. Cold Spring Harbor, NY: Cold Spring Harbor Laboratory.

Sanger, F., Nicklen, S. \& Coulson, A. R. (1977). DNA sequencing with chain-terminating inhibitors. Proc Natl Acad Sci US.A 74, 5463-5467.

Schwabacher, H. (1959). A strain of mycobacterium isolated from skin lesions of a cold-blooded animal, Xenopus laevis, and its relation to atypical acid-fast bacilli occurring in man. $J$ Hyg 57, 57-67.

van Soolingen, D., Hermans, P. W. M., de Haas, P. E. W. \& van Embden, J. D. A. (1992). Insertion element IS1081-associated restriction fragment length polymorphisms in Mycobacterium tubercalosis complex species: a reliable tool for recognizing $M y$ obacterium bovis BCG. J Clin Microbiol 30, 1772-1777.

van Soolingen, D., de Haas, P. E. W., Hermans, P. W. M., Groenen, P. M. A. \& van Embden, J. D. A. (1993). Comparison of various repetitive DNA elements as genetic markers for strain differentiation and epidemiology of Mycobacterium tuberculosis. I Clin Microbiol 31, 1987-1995.

Thompson, J. D., Higgins, D. G. \& Gibson, T. J. (1994). Clustal w: improving the sensitivity of progressive multiple sequence alignment through sequence weighting, position-specific gap penalties and weight matrix choice. Nucleic Acids Res 22, 4673-4680.

Tortoli, E., Piersimoni, C., Bacosi, D., Bartoloni, A., Betti, F., Bono, L., Burrini, C., De Sio, G., Lacchini, C., Mantella, A., Giulo Orsi, P.,
Penati, V., Tullia Simonetti, M. \& Bottger, E. C. (1995). Isolation of the newly described species Mycobacterium celatum from AIDS patients. J Clin Microbiol 33, 137-140.

Wayne, L. G., Good, R. C., Böttger, E. C., Butler, R., Ezaki, T., Gross, W., Jonas-Taggart, V., Kilburn, J., Kirschner, P., Krichevsky, M. I., Ridell, M., Shinnick, T. M., Springer, B., Stackebrandt, E., Tarnok, I., Tarnok, Z. S., Tasaka, H., Vincent, V. \& Warren, N. G. (1996). Semantide and chemotaxonomic based analyses of some problematic phenotypic clusters of slowly growing mycobacteria : a cooperative study of the International Working Group on Mycobacterial Taxonomy. Int J Syst Batteriol 46, 280-297.

Wayne, L. G. \& Sramek, H. A. (1992). Agents of newly recognized or infrequently encountered mycobacterial diseases. Clin Microbiol Rev 5, 1-25.

Wheatcroft, R. \& Laberge, S. (1991). Identification and nucleotide sequence of Rbizobium meliloti insertion sequence ISR $m 3:$ similarity between the putative transposase encoded by ISR $m 3$ and those encoded by Stapbylococcus aureus IS 256 and Thiobacillus ferroxidans IST2. J Bacteriol 173, 2530-2538.

Wolinsky, E. (1979). Mycobacterial diseases other than tuberculosis. Clin Infert Dis 15, 1-10.

Zolg, J. W. \& Philippi-Schulz, S. (1994). The superoxide dismutase gene, a target for detection and identification of mycobacteria by PCR. I Clin Microbiol 32, 2801-2812.

Received 19 January 1996; revised 25 March 1996; accepted 17 April 1996. 